\title{
‡USGS
}

science for a changing world

Prepared in cooperation with the

Massachusetts Department of Environmental Protection and the Massachusetts Department of Environmental Management

\section{Borehole characterization of a methane-yielding bedrock well, Tyngsborough, Massachusetts}

By Herbert A. Pierce, Gregory J. Walsh, Robert C. Burruss, and James R. Degnan

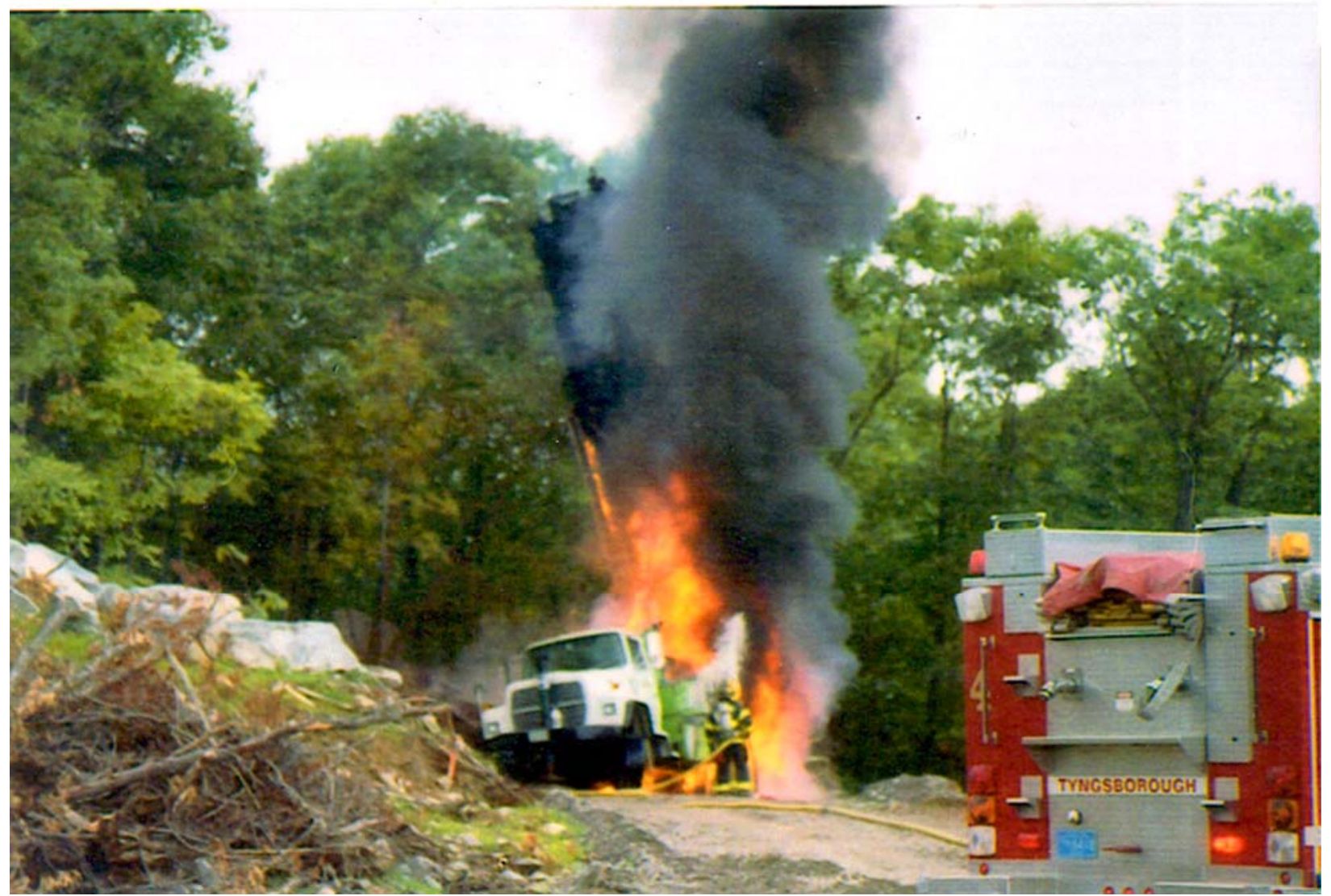

Open-File Report 2007-1399

U.S. Department of the Interior

U.S. Geological Survey 


\section{U.S. Department of the Interior DIRK KEMPTHORNE, Secretary}

\section{U.S. Geological Survey Mark D. Myers, Director}

U.S. Geological Survey, Reston, Virginia 2007

Revised and reprinted: 2007

For product and ordering information:

World Wide Web: http://www.usgs.gov/pubprod

Telephone: 1-888-ASK-USGS

For more information on the USGS - the Federal source for science about the Earth, its natural and living resources, natural hazards, and the environment:

World Wide Web: http://www.usgs.gov

Telephone: 1-888-ASK-USGS

Cover Photograph: The Tyngsborough Fire Department responds to a burning drill rig operated by Skillings and Sons, Inc. after an explosive methane release in August 2004. Photograph provided by Joseph Cerutti, Massachusetts Department of Environmental Protection.

Suggested citation:

Pierce, H.A., Walsh, G.J., Burruss, R.C., and Degnan, J.R., 2007, Borehole characterization of a methaneyielding bedrock well, Tyngsborough, Massachusetts: U.S. Geological Survey Open-File Report 20071399, http://pubs.usgs.gov/of/2007/of2007-1399.

Any use of trade, product, or firm names is for descriptive purposes only and does not imply endorsement by the U.S. Government. Although this report is in the public domain, permission must be secured from the individual copyright owners to reproduce any copyrighted material contained within this report. 


\section{Contents}

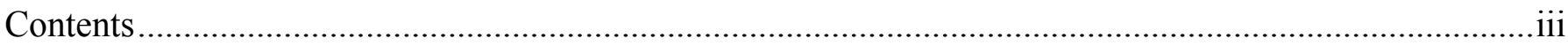

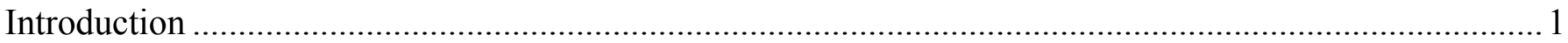

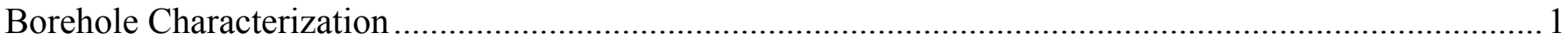

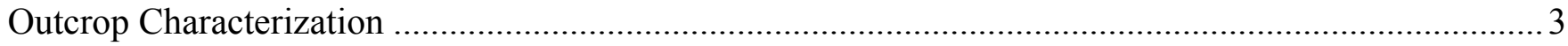

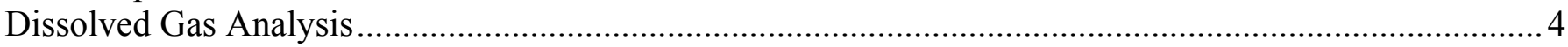

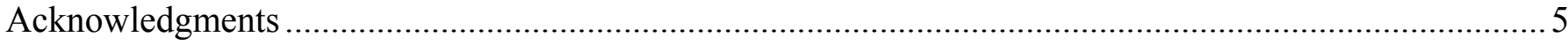

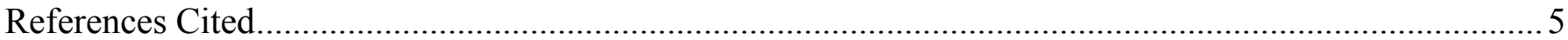

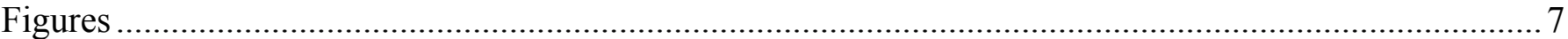

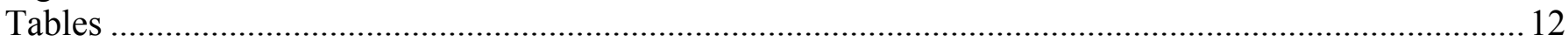

\section{Figures}

Figure 1. Location map showing the bedrock well, nearby outcrops, and a cross section (A-A') through the well from Scribner Road to Westford Road...............................................................

Figure 2. Plot of fracture locations and type by depth in the borehole................................................ 8

Figure 3. Plot of geophysical properties measured in the Skyline Drive well ....................................9

Figure 4. Lower hemisphere equal area projection showing the orientation and type of fractures at the Alpine Way roadcut, and photograph of the roadcut.

Figure 5. Lower hemisphere equal area projections of measured structures observed in the borehole.10

Figure 6. Photograph of Isotech Isobag showing in-situ sample from the bottom of the well with exsolved gas bubbles

Figure 7. Hydrocarbon molecular composition versus the carbon isotopic composition of methane for gases in table 2 showing the fields for gases of microbial origin and petroleum gases from thermogenic cracking of sedimentary organic matter

\section{Tables}

Table 1. Water level measurements made by water level probe in the Skyline Drive well, Tyngsborough, Massachusetts

Table 2. Molecular and isotopic compositions of gases in groundwater from wells in crystalline basement rocks, Massachusetts 


\section{Conversion Factors}

\section{Inch/Pound to SI}

\begin{tabular}{lcl}
\hline \multicolumn{1}{c}{ Multiply } & By & \multicolumn{1}{c}{ To obtain } \\
\hline Length & & \\
\hline inch (in.) & 2.54 & centimeter $(\mathrm{cm})$ \\
inch (in.) & 25.4 & millimeter $(\mathrm{mm})$ \\
foot (ft) & 0.3048 & meter $(\mathrm{m})$ \\
mile (mi) & 1.609 & kilometer $(\mathrm{km})$ \\
mile, nautical (nmi) & 1.852 & kilometer $(\mathrm{km})$ \\
yard (yd) & 0.9144 & meter $(\mathrm{m})$ \\
\hline
\end{tabular}

Temperature in degrees Celsius $\left({ }^{\circ} \mathrm{C}\right)$ may be converted to degrees Fahrenheit $\left({ }^{\circ} \mathrm{F}\right)$ as follows:

${ }^{\circ} \mathrm{F}=\left(1.8 \times{ }^{\circ} \mathrm{C}\right)+32$

Temperature in degrees Fahrenheit $\left({ }^{\circ} \mathrm{F}\right)$ may be converted to degrees Celsius $\left({ }^{\circ} \mathrm{C}\right)$ as follows:

${ }^{\circ} \mathrm{C}=\left({ }^{\circ} \mathrm{F}-32\right) / 1.8$

Vertical coordinate information is referenced to the insert datum name (and abbreviation) here, for instance, "North American Vertical Datum of 1988 (NAVD 88)"

Horizontal coordinate information is referenced to the insert datum name (and abbreviation) here, for instance, "North

American Datum of 1983 (NAD 83)"

Altitude, as used in this report, refers to distance above the vertical datum.

Specific conductance is given in microsiemens per centimeter at 25 degrees Celsius $\left(\mu \mathrm{S} / \mathrm{cm}\right.$ at $\left.25^{\circ} \mathrm{C}\right)$.

Concentrations of chemical constituents in water are given either in milligrams per liter $(\mathrm{mg} / \mathrm{L})$ or micrograms per liter $(\mu \mathrm{g} / \mathrm{L})$. 


\title{
Borehole Characterization of a Methane-Yielding Bedrock Well, Tyngsborough, Massachusetts
}

\author{
By Herbert A. Pierce, ${ }^{1}$ Gregory J. Walsh, ${ }^{2}$ Robert C. Burruss, ${ }^{1}$ and James R. Degnan ${ }^{3}$
}

\section{Introduction}

In August 2004, a domestic water well was drilled into granitoid metamorphic rocks 5.38 kilometers southwest of Tyngsborough, Massachusetts on Scribner Hill (fig. 1). According to well driller Roger Skillings of Skillings and Sons, Inc. (oral commun., 2005), no water was encountered during drilling and when the borehole reached a depth of approximately $305.1 \mathrm{~m}$, a blue flame exploded out of the well casing and ignited the drill rig, resulting in a total loss of the equipment (cover). Follow up water quality studies by the Massachusetts Department of Environmental Protection (Stephen Hallem, oral commun., 2006) detected low levels of methane in the groundwater extracted from the well. Discussions with the Stephen Hallem, Massachusetts Departments of Environmental Protection and David Wunsch, the New Hampshire State Geologist, prompted the USGS to further investigate this methane occurrence in granitoid rock. Borehole characterization and water quality sampling reported here were completed in May and June 2006, in an effort to identify the potential source of the methane. Follow up samples yielded no detectable methane, and for that reason this report presents a brief summary of our preliminary findings.

Our findings show that the well has many fractures but none clearly discernible at the bottom of the well $(305.1 \mathrm{~m})$. The deepest observable fracture occurs near the bottom of the well at a depth of $294 \mathrm{~m}$. The original methane was probably stored in this deep fracture or an unobservable fracture at the very bottom of the well $(305.1 \mathrm{~m})$, and released during drilling. We can only speculate about the initiation of the explosion. Perhaps a spark was generated by static electricity as the gas escaped or by the dry drill bit-rock interaction producing a piezoelectric effect caused by the applied mechanical stress of drilling. Microbial action may be responsible for depleting the methane in the well to limits below detection.

\section{Borehole Characterization}

In May and June 2005, borehole characterization of the well was completed with the following instruments:

- Three arm caliper (with natural gamma)

- Induction (rock resistivity and conductivity with natural gamma)

- Electrical log (Fluid conductance, resistivity, and temperature)

\footnotetext{
${ }^{1}$ USGS, Reston, Virginia

${ }^{2}$ USGS, Montpelier, Vermont

${ }^{3}$ USGS, Pembroke, New Hampshire
} 
- Optical Televiewer (oriented)

- 1 liter down hole water sampler

Results of the borehole characterization logs are included in this report in WellCAD log (WCL) format. The logs are located on the DVD in the file, Tyngsborough.WCL, that accompanies this text. The WellCAD Reader software is provided on the DVD and must be installed in order to view, scale, and print the logs. Use file wcad.reader.4.2.exe to install the WellCAD Reader. For additional information on WellCAD, please visit: http://www.rockware.com/catalog/pages/wellcad.html or http://www.alt.lu

A summary of the borehole findings includes

- The borehole is drilled through granodiorite, pegmatite, foliated granite, and metasedimentary rocks of the Silurian and Ordovician Devens-Long Pond facies of the Ayer Granite and the Silurian and Ordovician Berwick Formation (fig. 1) (Zen, 1983).

- During the time of logging, the water table ranged from approximately 39 to $46 \mathrm{~m}$ below ground surface (table 1).

- The borehole diameter is stepped but generally uniform, smooth, and $305.1 \mathrm{~m}$ deep (fig. 3).

- Gently to moderately dipping fractures occur throughout the borehole in the igneous rocks, but are not apparent in the Berwick Formation.

- Fractures that cross the foliation "crossing fractures" are more common than fractures along the foliation "parting fractures"; (fig. 2 and the borehole log).

- The deepest measurable fracture occurs at a depth of $294.4 \mathrm{~m}$. The fracture is approximately parallel to the foliation (parting), and occurs at the top of a thin $(20 \mathrm{~cm}$ thick) zone with a relatively higher concentration of leucocratic material (granite or pegmatite). Highly reflective minerals interpreted as pyrite are present in this zone.

- No distinct fractures were detected at the bottom of the well. At the bottom, the caliper $\log$ indicates that the borehole is cylindrical and measures $14.47 \mathrm{~cm}$ in diameter.

- Rock types in the borehole appear to be the same as rock types at nearby outcrops. The main rock type is granodiorite of the Ayer Granite.

The nature of borehole logs is such that normally a suite of logs are collected. At this well we employed various borehole probes; each probe collects several physical property measurements. Though some measurements are redundant this approach is applied because two logs may provide answers that may not be possible with either log separately, and each additional log may add much more to an understanding of the system (Keys, 1989). 
Combined physical property data can be used to provide other useful information about a borehole such as volume, structure, strike and dip, fracture apertures and sizes, fracture density, borehole deviation, and lithologic contacts.

\section{Outcrop Characterization}

Geologic characterization of nearby outcrops was conducted for comparison with the borehole. Nearby outcrops consist largely of Ayer Granite with screens and xenoliths of Berwick Formation metasedimentary rocks. Both the Ayer and the Berwick contain crosscutting dikes and sills of foliated biotite granite and granite pegmatite. The biotite granite resembles the nearby Devonian Chelmsford Granite. Fracture characterization was conducted at a large roadcut on Alpine Way (fig. 4) and included measurement of all fractures over a distance of $25 \mathrm{~m}$ with trace length $\geq 1 \mathrm{~m}$ on the western end of the roadcut. The rock type is dominantly biotite granodiorite with 1-2 cm microcline megacrysts. There are two large foliation-parallel xenoliths or screens ( 1-2 $\mathrm{m}$ thick) of Berwick Formation biotite-quartz-plagioclase granofels and calc-silicate granofels within the roadcut (fig. 4). Smaller xenoliths of Berwick Formation are visible on the top of the outcrop on the south side of the road. The Berwick Formation and the Ayer Granite share the same dominant foliation; in other words, both rocks pre-date the major foliationproducing deformation event in the crystalline rocks. The Berwick Formation is rusty weathering and locally sulfidic. The Ayer Granite is rusty weathering near the contacts with Berwick. Some fresh, non-rusty sulfides were seen in the Ayer. A summary of the findings includes

1. Sheeting fractures (low angle joints $\left(<20^{\circ}\right)$ often associated with parallel foliation, rock cleavage, or quartz veins) some with water seeps, generally strike NNW and dip gently ENE. Most are blind (not continuous) and planarity is moderate to low. Spacing is $\sim 0.2-$ $1.0 \mathrm{~m}$, and increases with depth.

2. Steeply to moderately dipping foliation strikes NE and dips SE and shows occasional parting in the Ayer and well-developed parting in the Berwick. Foliation-parallel fractures are throughgoing.

3. NW striking, sub-vertical faults all show NE side-up relative motion with slickensides plunging moderately to the SE. General motion is left-lateral, north side up and to the NW. All faults are blind and show low to moderate planarity (in other words, some are slightly curved).

4. Steeply dipping very planar joints trending $\sim 170^{\circ}$ are throughgoing and cross all structures. They are not uniformly distributed across the outcrop, but occur in zones with $\sim 0.2-0.6 \mathrm{~m}$ spacing.

5. Subordinate fractures include steeply dipping, abutting and blind joints striking $\sim \mathrm{EW}$ to ENE. Trace lengths are generally $<2 \mathrm{~m}$.

6. Minor parting occurs along late, thin $(<10 \mathrm{~cm}$ thick $)$ NE striking tabular pegmatite dikes. 
7. The orientation of the dominant foliation is approximately the same in the borehole as it is in the roadcut. In the borehole, the approximate dip, dip direction and strike are $56^{\circ}$, $123^{\circ}, 33^{\circ}$. This orientation is approximately the same as the small fracture seen at 294.4 $\mathrm{m}\left(51^{\circ}, 123^{\circ}, 33^{\circ}\right)$.

Planar features measured in the borehole are shown in figures 3 and 5. A comparison with features observed in the borehole indicates the following:

- Gently to moderately dipping fractures (see item 1 above) are common to the borehole and the outcrop, as are steeply dipping E-W trending fractures (item 5 above). Northsouth trending fractures seen at the outcrop were not observed in the borehole (item 4 above).

- Foliation in the borehole is fairly uniform and has a similar orientation at the outcrop (item 2 above).

- Granite and pegmatite dikes in the borehole have many orientations, but show two preferred directions with a NE strike and a SE and NW dip; the former is parallel to the foliation.

\section{Dissolved Gas Analysis}

Water samples were collected from the well by the USGS in May and June 2006. In May 2006, water samples were collected from the bottom of the well with a stainless steel in-situ sampler and from approximately $73 \mathrm{~m}$ below ground surface with a turbine pump. Pumped samples were collected in $100 \mathrm{ml}$ glass vials closed with silicone septa using standard USGS sampling procedures for dissolved gases in groundwater. Aliquots from the bottom in-situ samples were collected in $100 \mathrm{ml}$ glass vials closed with silicone septa, but were exposed to air during shipping. Samples collected from the bottom of the well in June 2006 with an in-situ sampler were transferred from the sampler into gas sampling bags without exposure to air. All samples exsolved gas at the surface (fig. 6).

Analytical results are listed in table 2. In addition to USGS analyses, Table 2 includes an analysis of the Skyline Drive well performed by the Massachusetts Department of Environmental Protection (Mass DEP) in May 2005, and analyses of two samples from other bedrock wells in Massachusetts, also provided by the Mass DEP.

There are two obvious features in the molecular analyses in table 2 for the Skyline Drive well. The gases are dominated by nitrogen and oxygen, essentially air, and methane was not detected in the USGS samples taken in 2006 and the methane concentration in May 2005 in the sample taken by the Mass DEP was very low, only 0.288 molecular precent. Ethane was detected only in the Mass DEP sample, and all other hydrocarbon gases up to C6 (hexane) were below detection limits.

The only stable isotopic data for methane in the Skyline Drive well is the analysis of the Mass DEP sample that has a carbon isotopic composition of -41.28 permil relative to Pee Dee Belemnite Standard (PDB). One goal of the USGS sampling in 2006 was to confirm this value and provide an analysis of the hydrogen isotopic composition. This was not possible. The carbon 
isotopic composition of methane in other bedrock wells in Massachusetts ranges from -70 to -78 permil relative to PDB. The carbon isotopic composition of dissolved inorganic carbon ranged from -14.4 to -20.5 permil relative to PDB. The isotopic composition of nitrogen was measured in one sample with $\delta 15 \mathrm{~N}=0.29$ permil relative to air.

The origin of hydrocarbons in the Skyline Drive well is problematic because methane is no longer present. Unpublished isotope data and composition data from the Mass DEP (Stephen Hallem, written commun. 2006) are intriguing, but frustrating because duplicate measurements were not possible. The carbon isotopic composition of methane (no hydrogen isotope data unfortunately) is in the range of thermogenic petroleum gas (fig. 7), but the amount of ethane is low enough that this isotopic composition could be due to microbial oxidation of an original microbial gas that looks like the others. The concentration of methane that Hallem measured is so low that the gas would not be flammable. We could not measure methane in either of our samples, but present a hypothetical time line. The well produces "no water" but blows out enough flammable gas (has to be greater than about 30 percent methane) to start a fire when drilled in 2004. By May 2005, the water level in the well had recharged to its current level and the dissolved gas contained only 0.288 percent methane, a trace of ethane and measurable amounts of $\mathrm{He}$ and $\mathrm{H}_{2}$, but generally looked like atmospheric air. We sampled it a year later, find no detectable methane, $\mathrm{H}_{2}$, or $\mathrm{He}$, the gas looks like air, and the water recharge rate is clearly very, very low.

This suggests the methane content has decreased with time to essentially zero. This could be due to microbial oxidation. The original, flammable gas was most likely of microbial origin, probably by $\mathrm{CO}_{2}$-reduction, using $\mathrm{H}_{2}$ from redox reactions with water in the granite (Sherwood Lollar, and others, 1993). Once the system was opened, microbial oxidizers took over and consumed the remaining methane, at least in the well bore.

\section{Acknowledgments}

We would like to thank Paul Blain and Stephen Hallem of the Massachusetts Department of Environmental Protection for their cooperation in this study, and permission to publish water quality results. We thank Dr. David Wunsch, New Hampshire State Geologist, for assistance with Mass DEP sample collection. We also thank Michael Schena of Connell Construction for permission to study the well.

\section{References Cited}

Barton, G.J., Burruss, R.C., and Ryder, R.T., 1998, Water quality in the vicinity of Mosquito Creek Lake, Trumbull County, Ohio, in relation to the chemistry of locally occurring oil, natural gas, and brine: U.S. Geological Survey.

Bernard, B.B., Brooks, J.M., and Sackett, W.M., 1976, Natural gas seepage in the Gulf of Mexico: Earth and Planetary Science Letters, v. 31, p. 48-54.

Burruss, R.C., and Ryder, R.T., 2003, Composition of crude oil and natural gas produced from 14 wells in the Lower Silurian "Clinton" sandstone and Medina Group, northeastern Ohio and northwestern Pennsylvania: U.S. Geological Survey, p. 64. 
Keys, S.K., 1989, Borehole geophysics applied to ground-water investigations: National Water Well Association, Dublin, Ohio, 313 p.

Salvini, F., 2004, Structural Data Integrated System Analyzer software: (DAISY 4.01): Dipartimento di Scienze Geologiche, Universita degli Studi di "Roma Tre", Rome, Italy.

Sherwood Lollar, B., Frape, S.K., Fritz, P., Macko, S.A., Welhan, J.A., Blomqvist, R., and Lahermo, P.W., 1993, Evidence for bacterially generated hydrocarbon gas in Canadian Shield and Fennoscandian Shield rocks: Geochimica et Cosmochimica Acta, v. 57, p. 5073-5085.

Whiticar, M.J., 1999, Carbon and hydrogen systematics of bacterial formation and oxidation of methane: Chemical Geology, v. 161, p. 291-314.

Zen, E-an, editor, and Goldsmith, Richard, Ratcliffe, N.M., Robinson, Peter, and Stanley, R.S., compilers, 1983, Bedrock geologic map of Massachusetts: U.S. Geological Survey, scale 1:250,000. 


\section{Figures}

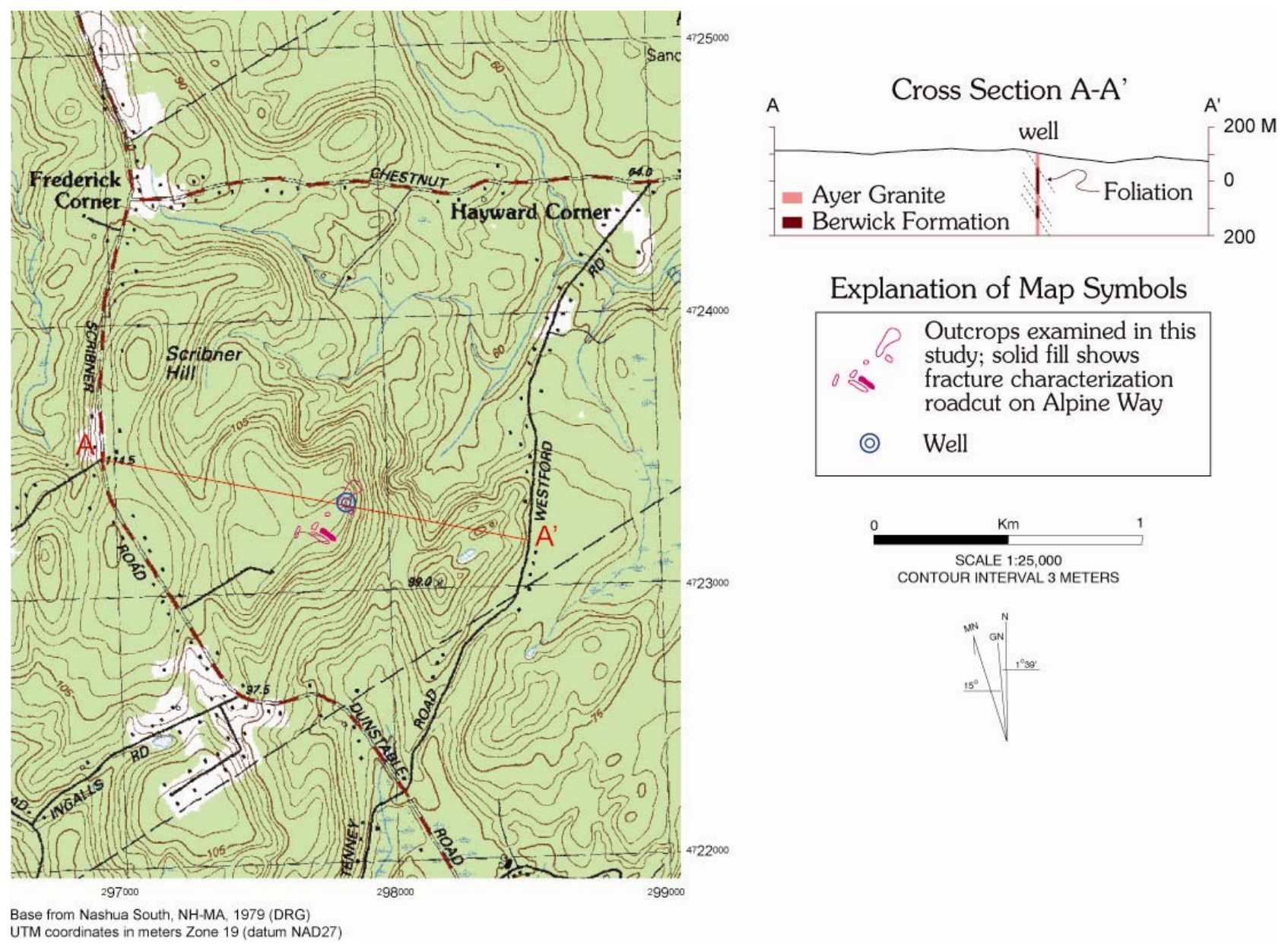

Figure 1. Location map showing the bedrock well, nearby outcrops, and a cross section (A-A') through the well from Scribner Road to Westford Road. 


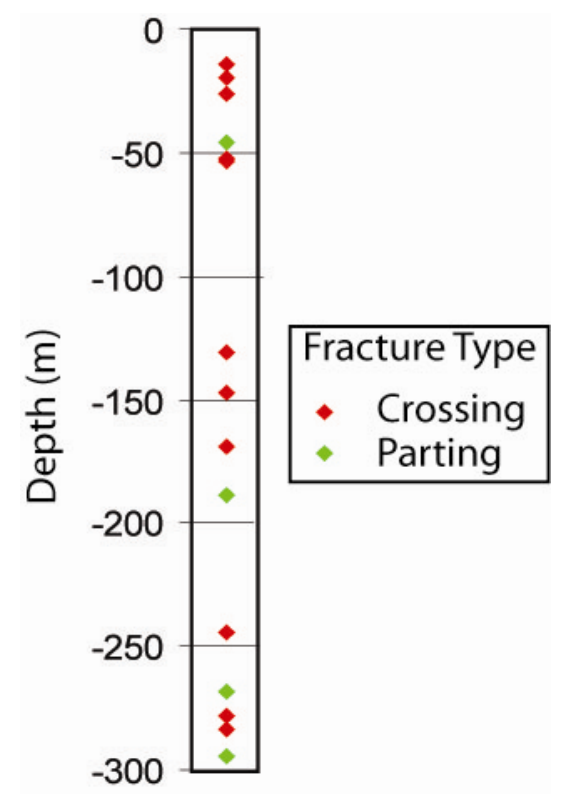

Figure 2. Plot of fracture locations and type by depth in the borehole. 


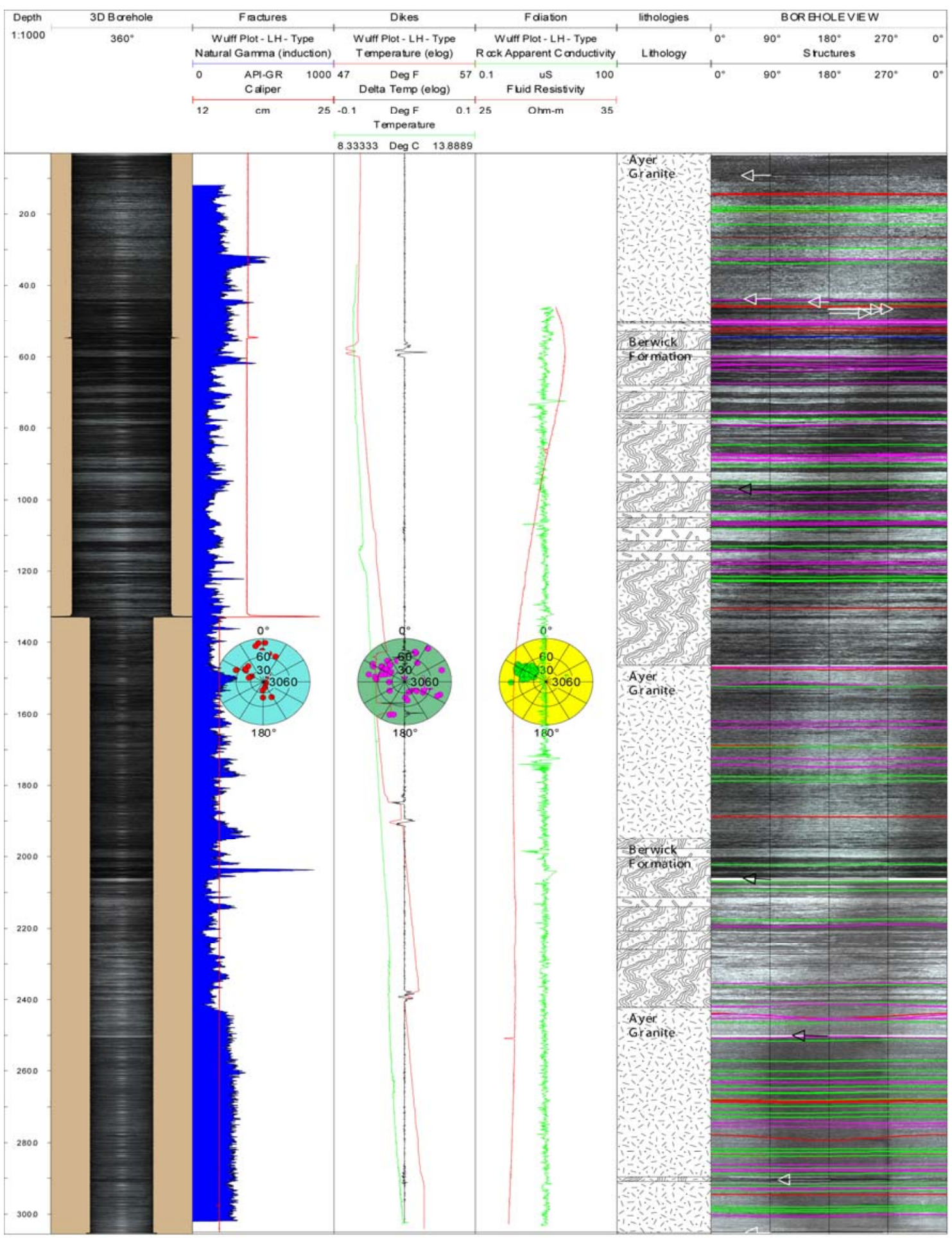

Figure 3. Plot of geophysical properties measured in the Skyline Drive well. Includes Wulff plots of measured foliation (green dots on Wulff plot correspond to green lines on borehole view), dikes (purple), and fractures (red) by depth (see also fig. 4). A scalable plot is included on the DVD but must be viewed with the WellCAD reader for the details in full resolution. 

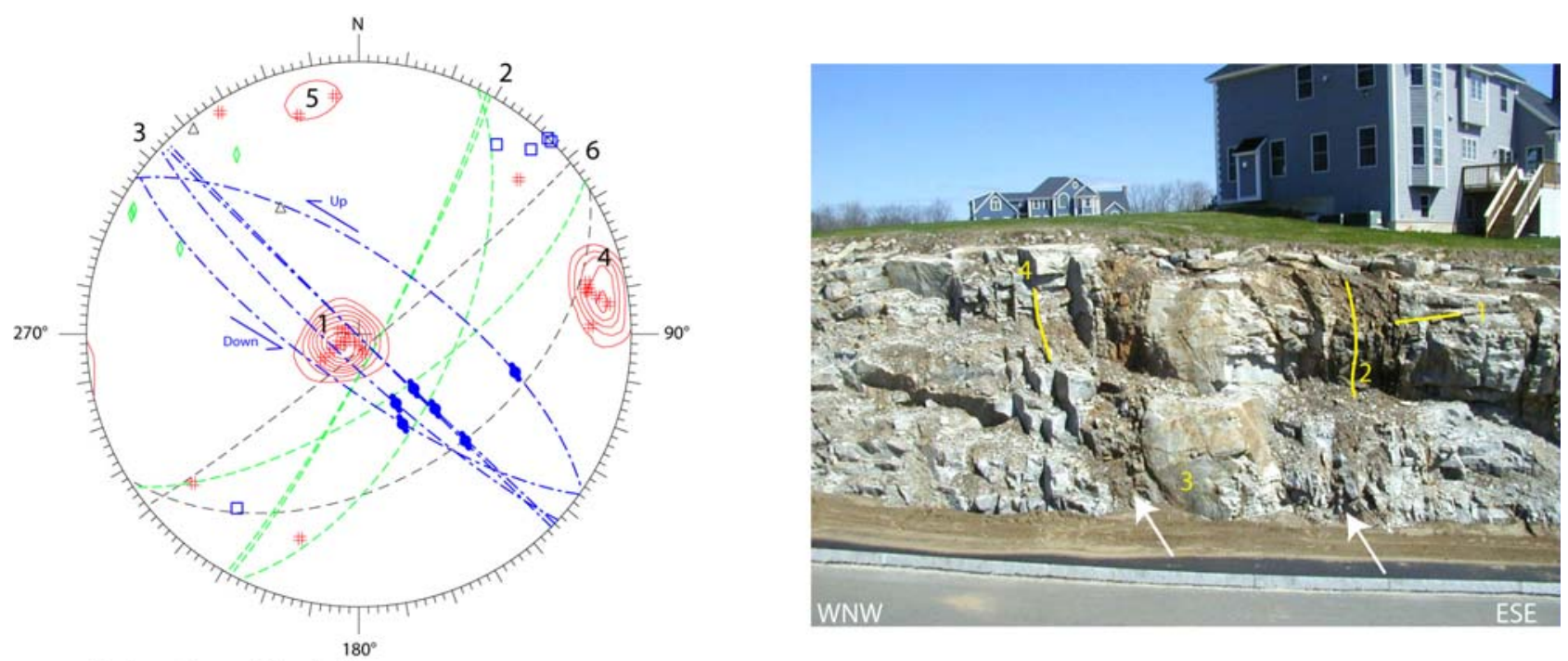

Explanation of Symbols

\begin{tabular}{|c|}
\hline $\begin{array}{l}\text { Fractures parallel to pegmatite dikes }(n=2) \\
\text { Poles to dikes }(n=2) \\
\text { Poles to joints }(n=21) \\
\text { Contoured poles to joints }(5 \%) \\
\text { Fractures parallel to foliation }(n=4) \\
\text { Poles to foliation }(n=4) \\
\text { Fractures parallel to faults }(n=5) \\
\text { Poles to faults }(n=5) \\
\text { Slickensides }(n=5)\end{array}$ \\
\hline
\end{tabular}

Figure 4. Lower hemisphere equal area projection showing the orientation and type of fractures at the Alpine Way roadcut, and photograph of the roadcut. Structural data plotted with Daisy software (Salvini, 2004). Numbers 1-6 (stereonet) and 1-4 (photograph) correspond to features described in the text. Arrows on the photograph show two large screens of Berwick Formation within the Devens - Long Pond facies of the Ayer Granite. View is looking to the north-northeast.

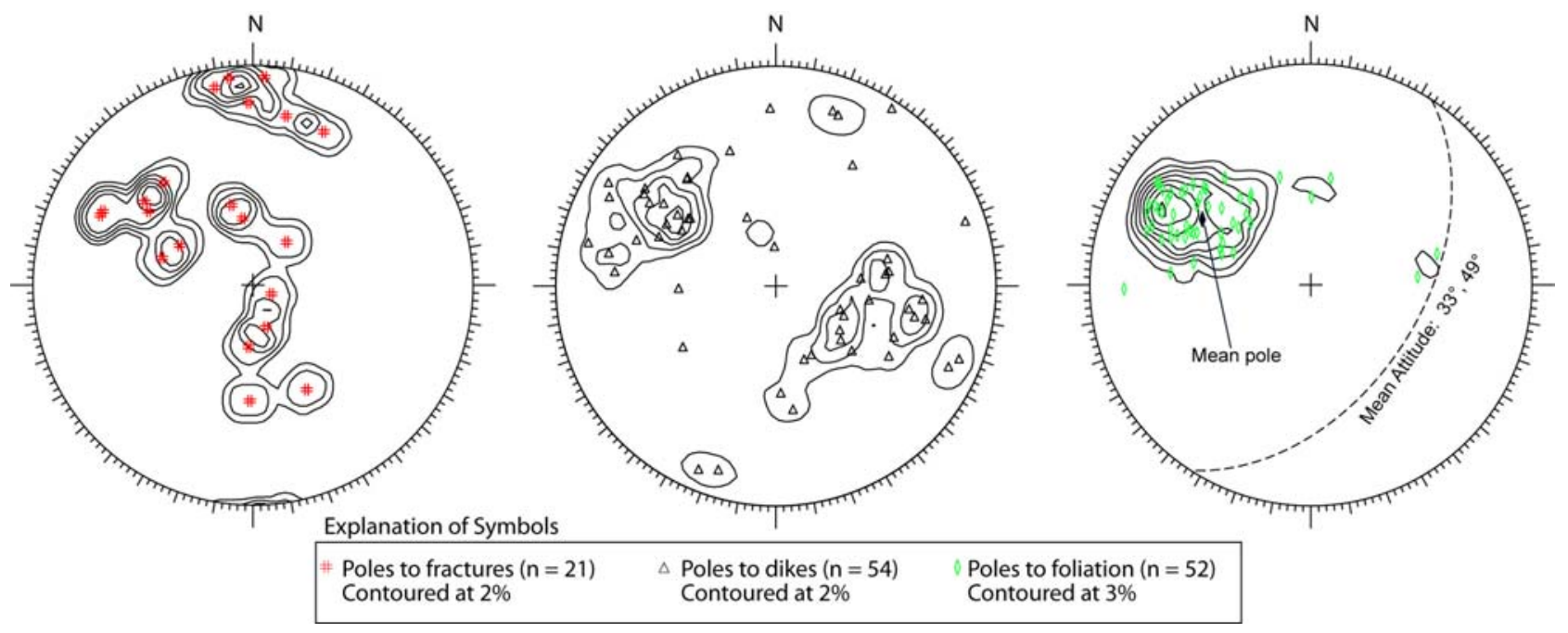

Figure 5. Lower hemisphere equal area projections of measured structures observed in the borehole. Structural data plotted with Daisy software (Salvini, 2004). 


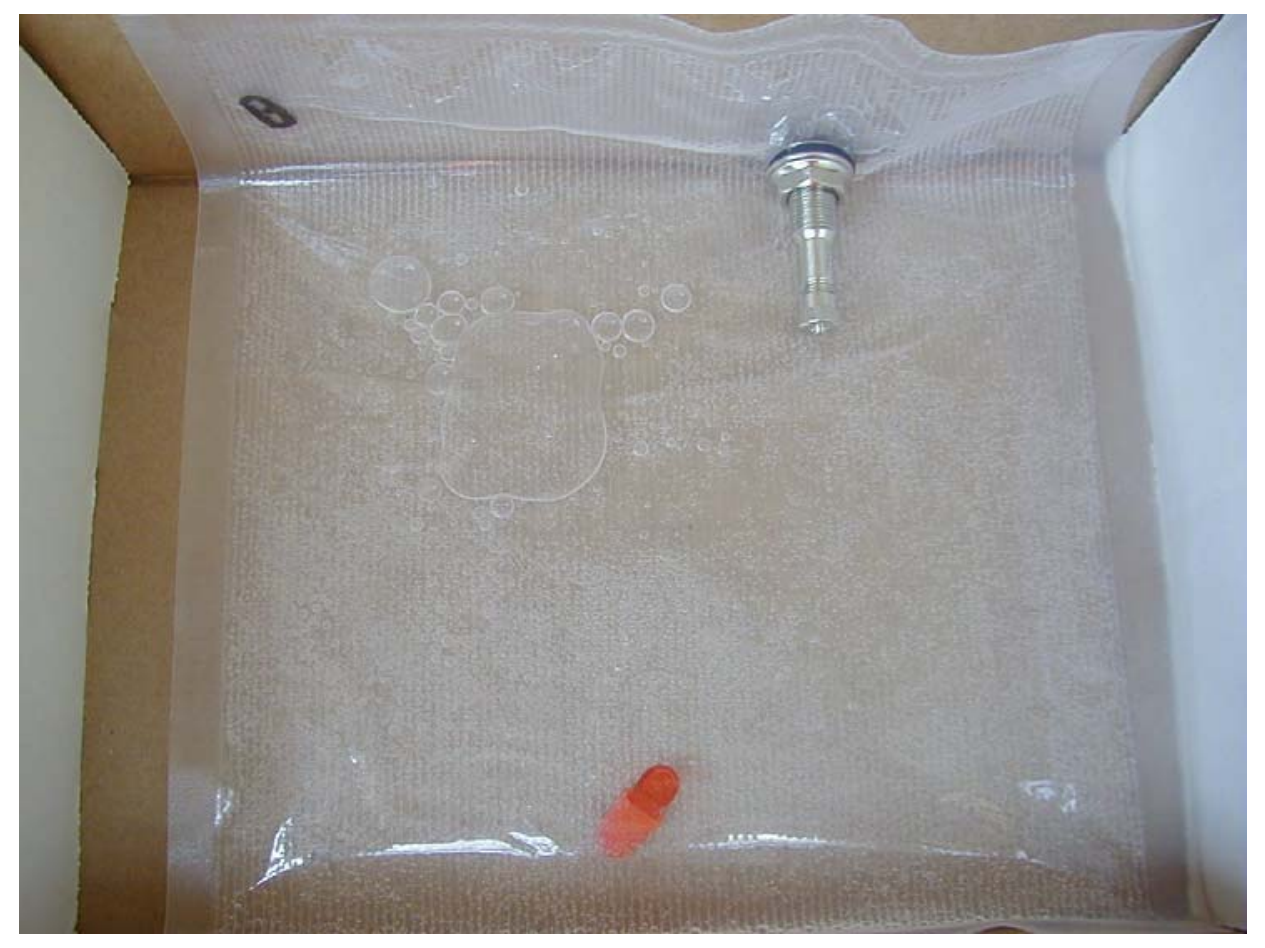

Figure 6. Photograph of Isotech Isobag showing in-situ sample from the bottom of the well with exsolved gas bubbles. Sample collected on June 20, 2006. 


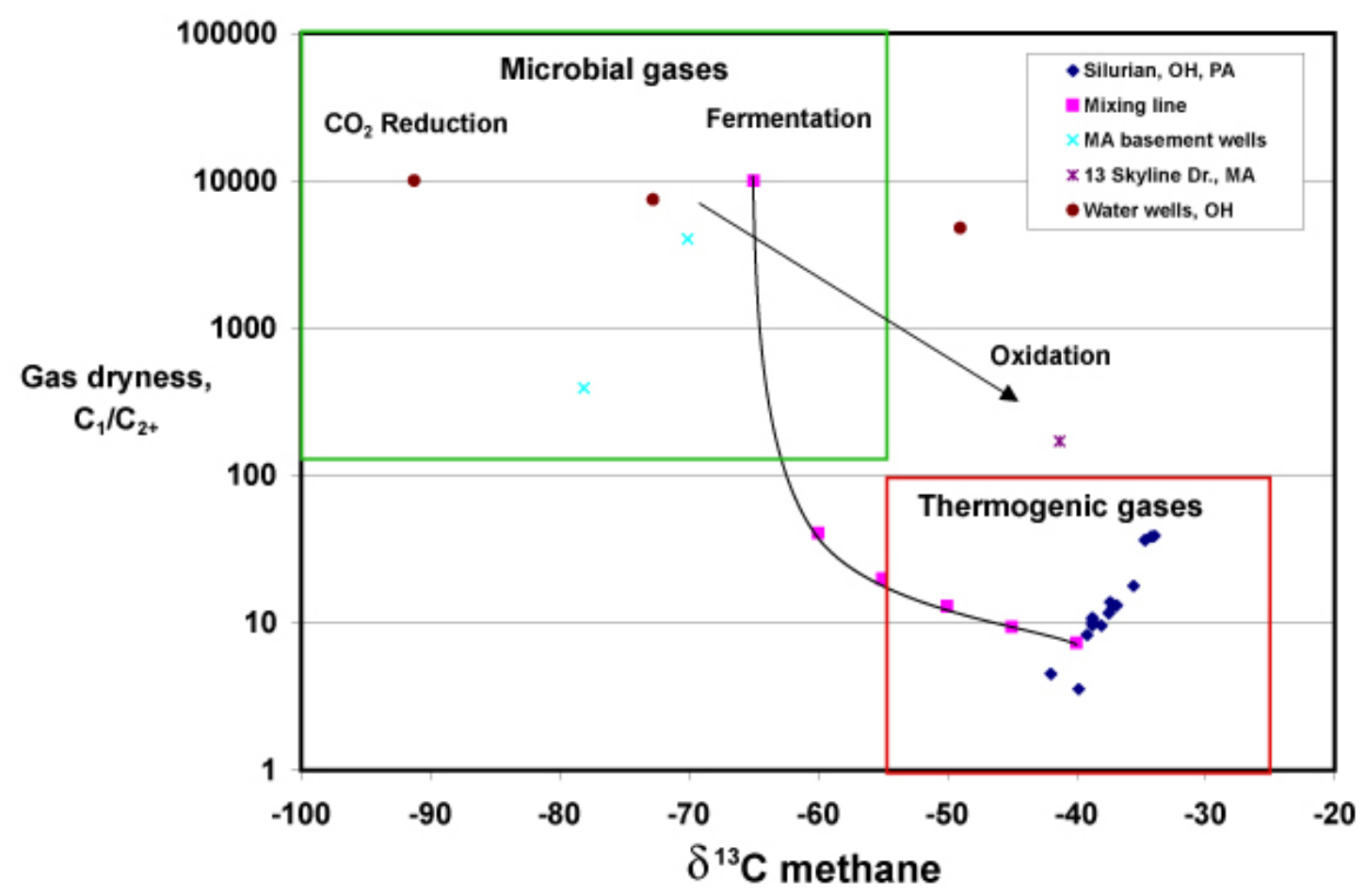

Figure 7. Hydrocarbon molecular composition versus the carbon isotopic composition of methane for gases in Table 2 showing the fields for gases of microbial origin (green box) and petroleum gases from thermogenic cracking of sedimentary organic matter (red box). The composition of gases that are oxidized by microbes can be shifted from the range for microbially generated gas toward thermogenic gas by partial removal of methane as indicated by the arrow (Bernard and others, 1976; Whiticar, 1999). In addition to the gases from crystalline bedrock in Massachusetts, the compositions of natural gases from Silurian age reservoirs in Ohio and Pennsylvania and shallow water supply wells in Ohio, are shown for comparison (Barton and others, 1998; Burruss and Ryder, 2003). The mixing line is calculated for gases with the endmember compositions with points for 20 percent increments of mixing. There is no evidence of mixing between microbial and thermogenic gases in the samples from Massachusetts. 
Table 1. Water level measurements made by water level probe in the Skyline Drive well, Tyngsborough, Massachusetts.

\begin{tabular}{cccc} 
Date & Time & $\begin{array}{c}\text { Depth to water below } \\
\text { ground surface }(\mathrm{m})\end{array}$ & Method \\
\hline \hline 2 May 2006 & $10: 15$ AM & 38.71 & water level probe \\
& & pumped unknown volume of water & \\
3 May 2006 & 09:00 AM & 45.64 & water level probe \\
4 May 2006 & 09:00 AM & 45.57 & water level probe
\end{tabular}

Table 2. Molecular and isotopic compositions of gases in groundwater from wells in crystalline basement rocks, Massachusetts.

\begin{tabular}{|c|c|c|c|c|c|c|c|c|c|c|c|}
\hline \multirow{3}{*}{$\begin{array}{l}\text { Isotech }^{1} \\
\text { Lab No. }\end{array}$} & \multirow{3}{*}{$\begin{array}{l}\text { Sample } \\
\text { Name }\end{array}$} & \multicolumn{10}{|c|}{ Molecular Composition } \\
\hline & & Location & $\mathrm{He}$ & $\mathrm{H}_{2}$ & $\operatorname{Ar}$ & $\mathrm{O}_{2}$ & $\mathrm{CO}_{2}$ & $\mathrm{~N}_{2}$ & $\mathrm{C}_{1}$ & $\mathrm{C}_{2}$ & \\
\hline & & Name & $\%$ & $\%$ & $\%$ & $\%$ & $\%$ & $\%$ & $\%$ & $\%$ & $\mathrm{C} 1 / \mathrm{C} 2+$ \\
\hline 81605 & $\begin{array}{l}\text { Deep well water } \\
\text { 06RCB13 Bottom }\end{array}$ & 13 Skyline Dr., Tyngsborough & 0.123 & 0.152 & 1.07 & 16.09 & 0.29 & 81.99 & 0.288 & 0.0017 & 169.4 \\
\hline 97779 & hole & 13 Skyline Dr., Tyngsborough & & & 1.37 & 21.94 & 0.79 & 75.90 & & & \\
\hline $\begin{array}{l}97780 \\
62006-\end{array}$ & 06RCB14 A & 13 Skyline Dr., Tyngsborough & & & 1.56 & 12.18 & 3.93 & 82.33 & & & \\
\hline 1 & 2919-C6620 & $\begin{array}{l}13 \text { Skyline Dr., Tyngsborough } \\
31 \text { Constantine Dr., }\end{array}$ & & & 1.33 & 24.93 & 0.96 & 72.78 & & & \\
\hline 88334 & 31 Constantine Dr. & Tyngsborough & & & 1.24 & 11.35 & 0.26 & 81.42 & 5.72 & 0.0147 & 389.1 \\
\hline 97781 & Wales Brookside & Wales Brookside & & & 0.977 & 3.97 & 0.061 & 82.57 & 12.42 & 0.0031 & 4006.5 \\
\hline
\end{tabular}

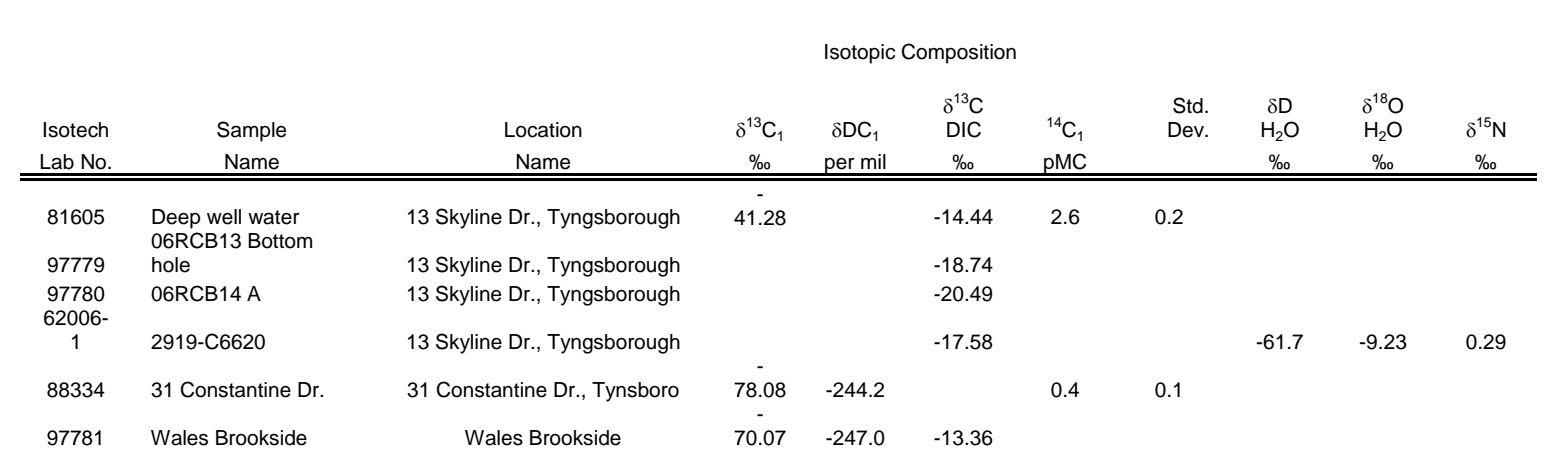

${ }^{1}$ Analyses by Isotech Laboratories, Inc., Champaign, Illinois. 